\title{
Development and Application Research of New Energy-saving Brick Based on Local Resources
}

\author{
Qiulan $\mathrm{Guo}^{\mathrm{a}}$ \\ School of Architecture Engineering, Xinyu University, Jiangxi 338004, China \\ a514149150@qq.com
}

Keywords: Energy-saving; the straw wall materials; Application status.

\begin{abstract}
This paper, taking the building energy-saving meaning as the starting point, expounded the application types of building energy-saving materials based on the local resources, focused on the development and application of the straw wall materials. And it also introduced the problems of energy-saving materials from the application status of contemporary architecture and put forward the continued promotion of building energy-saving brick.
\end{abstract}

\section{Introduction}

Brick, a retaining structure material, is the main material in different structures. So far, during the products on the market in China, solid clay brick accounts for most of the market share, but its thermal performance is far less than energy-saving brick, energy consumption in its production process is more than $50 \%$ of energy saving brick. In addition, the use of clay brick consumes huge amounts of clay resources, so it is equal to the destruction of arable land every year .

The development of new energy-saving building materials has become one driving way of promote China's architectural design and construction technology, and promote the building energy-saving materials to higher quality, decreasing energy consumption in the construction industry. The traditional autoclaved brick and coal gangue brick have opened the market, there is a development research of a part of river silt sintering energy saving brick, but the development research of energy-saving brick based on local construction waste, industrial slag, mining backfilling and south of straw is rare.

\section{Implication}

Building energy-saving refers to reduce energy consumption as much as possible on the conditions that meeting the same needs or achieving the same objective though the materials production, the building construction and occupation. it is generally considered that the rational use of energy, further improving energy utilization is building energy-saving.

Our country introduced related standard and promote the development of new type wall materials related documents, 10 ministries and commissions such as the national development and reform commission issued 201319 dictate to the measures for the administration of the comprehensive utilization of fly ash; Jiangxi province issued "promote the development of new wall materials in jiangxi province conditions".In addition, xinyu in response to national policy and complete the building energy efficiency 65\% target, work out the xinyu for development measures for the implementation of new wall materials and a series of policies.

\section{The development of local resources}

In order to meet the social demand for "energy conservation and emissions reduction", again to develop the use of local resources, focus on light weight, high strength, thermal insulation, energy conservation and emissions reduction requirements, around the society's need for green buildings, energy saving, break the traditional sticky clay bricks and autoclaved brick manufacturing,In xinyu, to local at iron and steel co., LTD under the ironmaking of blast furnace slag, village development 
hub mountain coal mine ore, the local rural crops such as rice, cotton stem developed is suitable for the new type energy saving brick "energy conservation and emissions reduction technology and manufacturing system.In this paper, Based on the crops straw stalks of wall materials of an example.

Xinyu as 3 cities in the south, the economy is not developed,Local rural main agricultural plants such as rice and cotton, rice and cotton straw as natural material,Is one of the byproducts in the process of agricultural production, often used as agricultural waste incineration, become the farmland fertilizer or part of the farmer's cooking burning materials, utilization accounts for only about 8\%, and cause air pollution.Crops straw possesses the advantages of lightweight insulation, but easy to burn.Magnesium oxychloride straw wall material is xinyu JiQuanLin new building materials co., LTD., the use of crops straw and magnesium oxychloride cement gelled material according to certain proportion of developed a new type of wall materials. The wall materials using straw as skeleton material and fiber reinforced material, make use of magnesium oxychloride cement gelled material, add specific modification additive, the fusion of the advantages of the two materials development and become a new type of environmental protection and energy saving materials.

In the case of magnesium chloride 260 be, According to table 1 mixture to make all specimens, after curing, try to match through a large number of tests, after bending strength, compressive strength, strength testing and related energy saving effectiveness indexes such as thermal conductivity test, its final determination of the optimal mixture ratio are shown in Table 1.

Table 1 Magnesium oxychloride cement gelled material proportion of actual table

\begin{tabular}{|c|c|c|c|c|c|}
\hline \multirow{2}{*}{ Serial number } & \multicolumn{3}{|c|}{ Gelled material consumption } & water-demand \\
\cline { 2 - 6 } & $\begin{array}{c}\text { magnesia } \\
\text { (MgO) (g) }\end{array}$ & $\begin{array}{c}\text { fly ash } \\
(\mathrm{g})\end{array}$ & $\begin{array}{c}\text { Halogen } \\
\text { liquid (ml) }\end{array}$ & $\begin{array}{c}\text { rice straw } \\
\text { (g) }\end{array}$ & \begin{tabular}{c} 
(water) (ml) \\
\hline 1
\end{tabular} \\
500 & 335 & 644 & 100 & 302.7 \\
\hline 2 & 500 & 335 & 670 & 110 & 299.3 \\
\hline 3 & 500 & 335 & 693 & 125 & 360.8 \\
\hline 4 & 500 & 335 & 720.4 & 145 & 352.6 \\
\hline 5 & 500 & 335 & 693.4 & 165 & 412.1 \\
\hline 6 & 500 & 335 & 696.3 & 175 & 473.8 \\
\hline mix proportion & 4.2 & 2.8 & 6.8 & 1 & 3.2 \\
\hline
\end{tabular}

According to table 1 mixture made of straw wall materials mechanics index conforms to China's current energy saving brick performance requirements, see the relevant indicators are shown in Table 2.

Table 2 The straw wall materials mechanics index table

\begin{tabular}{|c|c|c|c|c|}
\hline $\begin{array}{c}\text { group number } \\
(3 \text { al block })\end{array}$ & $\begin{array}{c}\text { Thermal } \\
\text { conductivity } \\
(\mathrm{W} / \mathrm{m} \cdot \mathrm{k})\end{array}$ & $\begin{array}{c}\text { 28d } \\
\text { rupture } \\
\text { strength }(\mathrm{MPa})\end{array}$ & $\begin{array}{c}\text { 28d } \\
\text { compressive } \\
\text { strength (MPa) }\end{array}$ & density (kg/m3) \\
\hline 1 & 0.148 & 1.23 & 1.89 & 1320 \\
\hline 2 & 0.156 & 1.28 & 2.38 & 990 \\
\hline 3 & 0.158 & 1.30 & 1.68 & 1026 \\
\hline 4 & 0.148 & 1.23 & 2.10 & 892 \\
\hline 5 & 0.147 & 1.15 & 1.81 & 905 \\
\hline 6 & 0.151 & 1.26 & 1.95 & 789 \\
\hline 7 & 0.148 & 0.78 & 1.86 & 758 \\
\hline 8 & 0.144 & 0.87 & 2.03 & 781 \\
\hline 9 & 0.149 & 0.76 & 1.92 & \\
\hline
\end{tabular}


Table 3 Common building wall materials mechanics index table

\begin{tabular}{|c|c|c|c|c|}
\hline Material varieties & $\begin{array}{c}\text { Thermal } \\
\text { conductivity } \\
(\mathrm{W} / \mathrm{m} \cdot \mathrm{k})\end{array}$ & $\begin{array}{c}\text { 28d } \\
\text { rupture strength } \\
(\mathrm{MPa})\end{array}$ & $\begin{array}{c}\text { 28d } \\
\text { compressive } \\
\text { strength (MPa) }\end{array}$ & density (kg/m3) \\
\hline concrete (C30) & 2.33 & 5.4 & 30 & $2000 \sim 2600$ \\
\hline Clay bricks (MU20) & 0.81 & 0.4 & 20 & 1800 \\
\hline Porous brick & 0.54 & - & 10 & 1100 \\
\hline Porous concrete & 0.078 & - & 3.0 & 480 \\
\hline Foam concrete & 0.076 & - & 0.5 & 285 \\
\hline $\begin{array}{c}\text { Composite } \\
\text { sandwich products } \\
\text { (A2.5) }\end{array}$ & 0.072 & - & 2.5 & 630 \\
\hline
\end{tabular}

Through and common building such as concrete, clay bricks, porous brick wall materials related to mechanics index comparison, specific see table 3.Though the strength of the straw wall materials products not as good as a regular wall materials such as concrete and sintered brick, but it can meet the bearing wall of multistory and filler wall strength requirements; its high flexural strength, tensile and shear strength of the common magnesium oxychloride materials have significantly improved, and impact resistance, fatigue resistance and toughness is improved substantially. Controlled by bulk density and thermal conductivity of materials thermal conductivity, is has the thermal insulation energy-saving wall materials.

Developed magnesium oxychloride straw wall materials, through the participation of the government and recommended, in each big economy applicable room area, such as: west Jiangxi pearl village, two resettlement community, merrill lynch bay area such as the trial, by the use efficiency of the detection of magnesium oxychloride straw wall materials not only has low density, high strength, small coefficient of thermal conductivity, and a series of traditional sintering masonry has no advantage, and high flexural strength, has a certain flexibility, its application is very wide development space in the future.

\section{Conclusion}

The development of new energy-saving building materials has become one driving way of promote China's architectural design and construction technology, and promote the building energy-saving materials to higher quality, decreasing energy consumption in the construction industry. This paper studies two kinds of energy saving brick: the crops straw stalks and tailings powder ash brick wall materials for our country in the application of energy-saving materials and energy-saving environmental protection has a positive exploration and practical application significance.

\section{References}

[1] Yu Sunguo. The development and utilization of panzhihua west slag field feasibility study [M]. Kunming University of science and master thesis, 2012.

[2] Zheng Gang. The use of new energy-saving materials and the development of reading architecture [J]. Energy and environment, 2010 (5) :86-88.

[3] Xue.Yongjie. The performance and application of new energy-saving building materials [J]. Guangdong chemical, 2011 (2):82-83. 
[4] Game studio, ANSYS 9.0 classic products based tutorials and example explanation [M]. Beijing: China water conservancy and hydropower press. 2012:146-223.

[5] Gong Shuguang, Huang Yunhai. The finite element analysis with ANSYS APDL programming and advanced application [M]. Beijing: Mechanical industry publishing house. 2011:168. 